\title{
Effect of Accounting Records on Financial Performance of Small and Medium Industries in Nigeria
}

\author{
Okpala, Lucy Ifeoma \\ Department of Accountancy, Chukwuemeka Odumegwu Ojukwu University, \\ Igbariam Campus, Anambra, Nigeria
}

\begin{abstract}
How to cite this paper: Okpala, Lucy Ifeoma "Effect of Accounting Records on Financial Performance of Small and Medium Industries in Nigeria" Published in International Journal of Trend in Scientific Research and Development (ijtsrd), ISSN: 24566470, Volume-3 | Issue-4, June 2019, pp.1120-1125, URL: https://www.ijtsrd.c om/papers/ijtsrd25 084.pdf

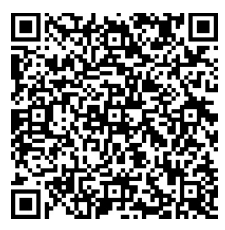

IITSRD25084
\end{abstract}

Copyright (C) 2019 by author(s) and International Journal of Trend in Scientific Research and Development Journal. This is an Open Access article distributed under the terms of the Creative Commons

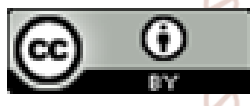
Attribution License (CC BY 4.0) (http://creativecommons.org/licenses/ by/4.0)

These establishments have tremendous impact on the state and well-being of the nation in employment generation, as sources of national outputs and revenues, providing feedstock for large corporations They may lack the sophistication to apply the detailed accounting processes, yet the value of accounting systems to these businesses is quite profound.

As business unit becomes more complex and broader on scope, accounting evolved in response to the increased planning and control responsibilities of management. As government grows in size and becomes more centralized, accounting was developed to meet the increased accountability. Most often, business decisions need to be supported by quality financial information which needs to be relevant, user friendly and available in a timely manner (Abdulrasheed, Khadijat \& Oyebola, 2012). Where appropriate accounting should be an active steering tool to run and manage a business instead of representing another administrative burden that the sole proprietor has to comply with. It is important that the accounting systems for one man businesses should fulfill such functions as providing essential financial information for the owners and managers in order for them to be able to manage the business in a competitive environment and to make informed decisions to prevent business failure and to expand the business.
However, owners of one man businesses may have particular needs and conditions, so that accounting systems need to be flexible in order not to impose unnecessary operative burdens (Abdulrasheed et al, 2012).

Moreover, an accounting system records, retains and reproduces financial information relating to financial transaction flows and financial position. Financial transaction flows encompass primarily inflows on account of incomes and outflows on account of expenses. Elements of financial position, including property, money received, or money spent, are assigned to one of the assets, liabilities, and equity (Ezejiofor, Ezenyirimba \& Olise, 2014). Within these primary groups each distinctive asset, liability, income and expense is represented by respective "account".

According to Ismail and King (2007), the development of a sound accounting system in SMEs hinge on owners level of accounting knowledge and skills. Some authors have argued that small businesses use professional accounting firms for preparation of annual reports and for other accounting needs (Keasy \& Short, 1990). Lalin and Sabir (2010), reports that the main drivers why SMEs prepare financial statements is pressure from regulatory authorities.

Fitzgerald et al 2006 argue further that business enterprises must improve production if they are to effectively compete 
in this era of rapid economic and technical change. Improved productivity requires both capital investment as well as a work force that has the flexibility to acquire new skills for newly created jobs resulting from structural changes in the economy. Bititei et al (2001) asserts that performance is a result of workers because they provide the strongest linkage to strategic goals of the business enterprise, Customer satisfaction and economic contribution that affects the business, hence it addresses the mode in which an activity is accomplished in particular and the level of standards to which a task is carried out within the working environment.

Meanwhile, most of the studies such like Harash (2014), found that accounting information such as: reliability, relevance, timeliness, and accessible have significant effects on SMEs' performance. Olatunji (2013) results showed that adoption of sound accounting system enhances performance of small and medium scale businesses. Mwebesa, Kansiime, Asiimwe, Mugambe and Rwego (2018) also found positive relationship between accounting records and performance of small and medium enterprises. Among these studies, none had been carried out in Anambra State. According to Ikechukwu (1993), keeping records is crucial for the successful performance of a business. A comprehensive record keeping system makes it possible for entrepreneurs to develop accurate and timely financial reports that show the progress and current condition of the business. With the financial report generated from a good recordkeeping system, performance during one period of time (month, quarter or year) with another period can be compared.

Based on the above development, this study therefore determines the effect of financial records on financial performance of small and medium industries in Anambra State, Nigeria. Specifically to:

1. Determine whether small and medium industries keep accounting records of their financial transactions in Anambra state.

2. Evaluate whether sound accounting system significantly improve the performance of small and medium industries in Anambra State.

\section{Review of related Literature Financial Records}

According to Ademola, Olukotun, Samuel and Ifedolapou (2012), financial record keeping is the foundation on which modern businesses thrive for growth and sustainability. Meanwhile, businesses are highly depends on financial records kept in the books of accounts showing different transactions such as sales, purchases, income, and payments by an individual or organizations (Dawuda \& Azeko, 2015).

For several groups to perform coherently, efficiently, effectively and ensure profitability, they must keep financial records (Ozotambgo, 2015; Trived \& Shilpa, 2010). Good financial records, however, can greatly improve many of the management decisions a business owner and or manager takes, including decisions about marketing, personnel, borrowing, pricing, inventory, and product development (Muchira, 2012). Such financial records include; income statement, statement of financial position (balance sheet), the statement of Cash flows, and the financial internal control system records that check the accuracy of company transactions (Ssekajugo etal., 2013).

It is believed that record keeping has a significant impact on financial performance of a given business. For example,
Onaolapo (2014) asserts that record keeping gives substantial information about the financial strength and current performance of an enterprise and therefore managers find those records useful in making decisions. Maseko and Manyani (2011) and Amoako (2013) both affirmed that financial record keeping and financial transparency are inseparable. Complementarily, Muchira (2013) agreed that good record keeping will make any business partner or investor more aware of what is going on in their businesses and it will save them money.

An account is simply a record of financial inflows and outflows in relation to the respective asset, liability, income or expense. Income and expense accounts are considered temporary accounts, since they represent only the inflows and outflows absorbed in the financial-position elements on completion of the time period (Williams, Haka, Bettner, \& Carcello, 2008).

In most industries, comparability will be affected by size. Larger firms will be able to avail themselves economic and certain sophisticated quantitative management techniques that may not be practicable for small ones. Smaller companies may be able to maintain closer client relation and better customer relation than the larger ones. This difference in operation technique may influence deficit in accounting method employed in generating financial information (Abdulrasheed, Khadijat \& Oyebola, 2012).

\section{Small and Medium Scale Businesses}

The small businesses may not even have kept any records at all but for tax purposes. It should be remembered that accounting is aid to management and not an end in itself. It is therefore only fair to expect that the small and medium scale businesses would not incur costs above justified limits (Iopev and Kwanum, 2012; Bamiduro, 2003). Niswonger and Fess (1969) insists "each system must be designed to fit the nature of the individual enterprise, the volume of transactions of various types, and the number and the capacities of the personnel. Internal control in small and medium scale enterprises may not be as detailed as those of large companies but it should comprehensively cater to the needs of the enterprises and users of its reports such that it provides reasonable assurance of truth and fairness (Mbroh, 2013).

According to Wood (1979), most of small businesses have all the information they want by merely keeping a cashbook and having some form of records, not necessarily in double entry system (Olaoye, 2012). This is an aberration and requires a conversion to double entry system for meaningful reporting (Onaolapo, et al. 2011). The mechanics of the conversion involve the preparation of a statement of affairs and estimation certain data for the updates of full set of ledgers and henceforth a complete double entry system is installed (Pickles \& Lafferty, 1974).

According to Ademola et al (2012),Small scale enterprises are catalysts for catalysts for world's economic growth and development which have dominated the industrial sector of both developed and underdeveloped countries. Aruwa (2006) believed that Nigeria's industrial sector is dominated by small and medium scale enterprises (SMEs) which accounts for $90 \%$ in terms of number of enterprises, as compared with other developed countries where more than $98 \%$ of all their enterprises belong to SME sector, about $80 \%$ of the total industrial labour force in Japan is SME, 50\% in 
Germany, $46 \%$ in USA are employed in smaller firms. Central Bank of Nigeria defined small scale enterprises as all businesses with a total assets investment of less than one million, an annual turnover of less than one million and with a total number of employees of less than fifty (World Bank Mapping 2001). In addition, the International Finance Corporation (IFC) and Corporate Affairs Commission in 2001 further justified that Nigeria's industrial sector is dominated by SMEs, estimated to be about $90 \%$ of the sector employing less than $50 \%$ of the people (HPACI 2002). Given the place occupied by the SMEs in Nigeria's industrial sector, it is expected that the success of the Nigerian economy would be partly dependent on the success of the SMEs. Nwoye (1991) pointed out clearly that SMEs are catalysts for Nigeria's economic growth and development. He believe that through so many SMEs, Nigeria has great potentials for success and growth, sales of large volume of goods etc. Even though, some of them have adequate capital, many of them fail due to poor financial management operations (Ezejofor et al, 2014). Controls may have to depend on the close involvement of the owners in the management of the business and to extent of their integrity. This calls for an adaptation of accounting systems to need of these businesses (Abeygunasekera \& Fonseka, 2013). According to Morries (2007) Small businesses have some inherent disadvantageous characteristics that will require that they be provided with public supports. Such characteristics, apart from limited managerial capabilities, include lack of economies of scale, lack of collective voice and influence on policy, frequent cases of market failures and/or biases against small businesses, weak financial capacity to undertake R\$D or the costly support services such as Business Development Service (BDS), and huge knowledge gaps (most small business promoters don't know what they need to know but which they don't know). When these public supports are not available, chances of failure can be very strong.

\section{Empirical Review}

Quite number of studies had been carried out on accounting records and performance of small and medium enterprises in Nigeria and beyond. The relationship between accounting Information systems and SMEs performance was conducted by Harash (2014), who tested the influence of characteristics enjoyed by the accounting information in determining SMEs performance. It was found that the characteristics enjoyed by the accounting information such as: reliability, relevance, timeliness, and accessible have significant effects on the use of AIS and SMEs' performance.

According to Oladejo (2008), the achievement of the firm's objectives is greatly influenced by the application of accounting records. Most businesses in Nigeria still are not aware of the importance and benefits of accounting records. It is found that accounting records are faced with some challenges which are inadequate infrastructural facilities, inability of most business firms to demand accounting systems adequate to them for their needs, lack of standardized professional body in accounting records and also local firms are been threatened by developed countries that are enjoying the full benefits of accounting records. He concluded that accounting records has contributed immensely to the unprecedented rate in the growth of small businesses in identifying the expenses, income, and profit and loss of a firm at the end of an accounting year.
Okoli (2011) links proper record keeping and profitability of small scale enterprises. In a study of 148 respondents in Nigeria (Enugu), and assert that due to inadequate record keeping, the small scale operators could not assess their performances effectively. He argues that in order to enhance the profitability of small scale enterprises and their continuity, there is need for adequate record keeping which will help the proprietors to keep track of the performance of these enterprises. Mensah et al. (2007) states that a significant number of enterprises in their survey kept no records pertaining to operations, finance, audited accounts, tax returns, and so on. Until recently, all the micro and small enterprise could not receive credit from the banks and promotional institutions on grounds that the formal banking sector considered them a high risk area, and hence charged them high cost for borrowed funds from the banks. Ezejiofor, Ezenyirimba and Olise (2014) determined the contributions of accounting records in efficient performance of small scale business. Two hypotheses were formulated in line with the objectives of the study. Survey method was adopted and data were collected through the use of questionnaire. Data generated were analyzed with means, standard deviation and weighted value and the hypotheses formulated were tested using Z-test statistical technique. The study found The training of accountants by these institution and the various professional institutes should focus more on practical means of solving accounts reporting needs of small and medium scale enterprises; and that government should provide adequate financial assistance, this is because if there is adequate financial support, more unemployed Nigerians will engage in small scale enterprises thereby gain their means of living easily than looking for unavailable while collar job.

Olatunji (2013) examined the impact of sound accounting system on corporate performance of small and medium scale enterprises. This was done by a survey carried out through questionnaire and analyzed using the F-Statistic (ANOVA) Results showed that adoption of sound accounting system enhances performance of small and medium scale businesses. Mwebesa, Kansiime, Asiimwe, Mugambe and Rwego (2018) carried out study in three rural districts of Rubirizi, Kasese and Rukungiri in Western Uganda with the aim of determining the effects of financial record keeping on financial performance of Development groups. A total of 99 respondents were obtained from 33 development groups. Data were entered in Epi data 3.1 and descriptive and correlational analyses were done using SPSS version 21. Using the Likert scale with five categories from strongly agree to strongly disagree, a mean value of 3.5 indicated a strong agreement to the questions asked. Findings revealed a significant positive relationship between the financial record keeping and financial performance.

Emad (2017) described the effects of accounting information system (AIS) on the accounting performance of Small and medium enterprises (SMEs). The results show a positive relationship between the AIS and accounting performance in Iraqi SMEs.

\section{Methodology}

The population for the study consists of small and medium industries in Anambra State. The researchers used judgmental sampling technique to select one hundred and seventy six representatives to other small and medium industries in Anambra State. 
International Journal of Trend in Scientific Research and Development (IJTSRD) @ www.ijtsrd.com eISSN: 2456-6470

\section{Method of Data Analysis}

The questionnaires were analysed and hypotheses formulated for the study were tested with the Univariate Analysis of Variance (UAV) for opinion differences, using the Statistical Package for Social Sciences (SPSS) version 20.0 software package.

\section{Software_Description}

Statistical Package for Social Sciences (SPSS) is a software solution utilized in data analysis after carefully inputting the variables used in the study.

\section{Decision Rule:}

Using SPSS, 5\% is considered a normal significance level. The accept reject criterion was based on the computed F-Value.

\section{DATA PRESENTATION, ANALYSIS AND INTERPRETATION Analysis of Data}

Table 1: showing mean ratings on accounting records on small and medium industries in Anambra State.

\begin{tabular}{|c|l|c|c|}
\hline S/N & \multicolumn{1}{|c|}{ Women has influence on } & Mean & Decision \\
\hline 1 & SMIs always keeps records of their transactions & 3.98 & Accept \\
\hline 2 & A times SMIs seek the service of an expert & 3.56 & Accept \\
\hline 3 & SMIs uses accounting records to monitor the strength and weakness of their transactions & 3.34 & Accept \\
\hline 4 & Accounting records is being kept in SMIs & 3.13 & Accept \\
\hline 5 & Accounting professionals usually provide professional advice to SMIs & 2.39 & Reject \\
\hline 6 & Sound accounting helps SMIs in debt management & 2.15 & Reject \\
\hline 7 & There is a records for financial asset of SMIs & 2.36 & Reject \\
\hline 8 & Sound accounting record has influence on SMIs income & 3.67 & Accept \\
\hline 9 & Sound accounting system gives insight on the cash flow & 2.86 & Reject \\
\hline 10 & Sound accounting system helps SMIs in their tax assessment & 2.67 & Reject \\
\hline \multicolumn{2}{|l|}{ Average Mean Ratings } & $\mathbf{3 . 0 1}$ & Accept \\
\hline
\end{tabular}

Source: Field Survey, (2019)

Findings on table 5 above shows that, items $1-4,8$ with mean ratings of $3.98,3.56,3.34,3.13$, and 3.367 are accepted as household decision women are involved during decision making in homes, while item 5-7, 9 and 10 are rejected considering the mean ratings of $2.39,2.15,2.36,2.86$, and 2.67 as decisions women do not contribution when household decisions are being taken.

\section{Test of Hypotheses}

Tests of Between-Subjects Effects

\begin{tabular}{|c|c|c|c|c|c|}
\hline Source & Type III Sum of Squares & Df & Mean Square & F & Sig. \\
\hline Corrected Model & $759.675^{\mathrm{a}}$ & 213 & 3.567 & 3.946 & .000 \\
\hline Intercept & 581.093 & 1 & 581.093 & 642.848 & .000 \\
\hline HYPOTHESIS1 & 14.237 & 11 & 1.294 & 1.432 & .178 \\
\hline HYPOTHESIS11 & 6.964 & 13 & 1.536 & 1.593 & .852 \\
\hline & & & & & \\
\hline HYPOTHESIS1 & 45.818 & 23 & 1.066 & 1.179 & .265 \\
\hline Error & 65.083 & 32 & .904 & & \\
\hline Total & 4135.000 & 176 & & & \\
\hline Corrected Total & 824.759 & 175 & & \\
\hline \multicolumn{7}{|c|}{ a. R Squared =.921 (Adjusted R Squared =.688) } \\
\hline
\end{tabular}

\section{Hypothesis One}

$\mathbf{H}_{\mathbf{0}}$ 1: Small and medium industries do not keep accounting records of their financial transactions in Anambra state. In table 2 above, ( $F$ value $=1.43$ and Sig value $=0.18$ ) thus, indicating that there is a significant difference and alternate hypothesis is accepted while null hypothesis is rejected. Therefore, the Small and medium industries keep accounting records of their financial transactions in Anambra state.

\section{Hypothesis Two}

$\mathbf{H}_{\mathbf{0}}$ 2: Sound accounting system does not significantly improve the performance of small and medium industries in Anambra State.
Decision: In table 2 above, the result obtained indicates that there is a significant difference at ' $F$ ', value $=1.593$ and 'Sig', value $=.852$ ) thus, alternative hypothesis is accepted while null hypothesis is rejected. Therefore, sound accounting system has significantly improved the performance of small and medium industries in Anambra State.

\section{Interaction Effect of the Hypotheses Hypothesis 1 and Hypothesis 11}

From table 2 above result indicates that hypothesis one interacted with hypothesis two and there was a significant interaction effect between the two hypotheses at point [F=1.18], [Sig=0.23], therefore the adoption of the two hypotheses: the small and medium industries keep accounting records of their financial transactions in Anambra state and the sound accounting system of small and medium industries in Anambra State will simultaneously influence the financial performance of small and medium industries in Anambra State. 


\section{Conclusion and Recommendations}

Accounting records plays a vital role in the growth and performance of SMIs to strive. However, the small and medium industries keep accounting records of their financial transactions and the sound accounting system of small and medium industries in Anambra State will simultaneously influence the financial performance of small and medium industries in Anambra State. Accounting records may not only influence high performance to the industries, it can flags up some vital activities that can lead to higher goals of the industries.

Efficiency of accounting records ensures that all levels of management get true information, sufficient enough for planning and increases the control and enhances the accounting performance in small and medium industries.

Based on this, it recommended that the cost of operating sound accounting system should be minimized in order to encourage the adoption of in small and medium industries in the State. More effort should be allocated to accounting records for effective performance of small and medium industries.

\section{References}

[1] Abdulrasheed A., Khadijat A., \& Oyebola F. E,(2012) Accounting Principles of Small Enterprises in Ilorin Metropolis of Kwara State, Nigeria Research Journal of Finance and Accounting www.iiste.org ISSN 2222-1697 (Paper) ISSN 2222-2847 (Online) 3(2).

[2] Ademola, G. O., James, S. O., \& Olore, I. (2012). The roles of record keeping in the survival and growth of small scale enterprisesin Ijumu Local Government Area of Kogi State. Global Journal of Management and Business Research, 12(13).

[3] Aruwa, S. A. (2006). The Business Entrepreneur, Academy Publication, Kaduna, Nigeria.

[4] Amoako, G. K. (2013).Accounting Practices of SMEs: A Case Study of Kumasi Metropolis in Ghana. International Journal of Business and Management, 8(24). http://dx.doi.org.10.5539/ijbm.v8n24p73

[5] Babarinde A. (2003) Financial Accounting, Volume 1, Lagos: JBA Associates Ltd, p 313

[6] Bamiduro, J. A (2003). An Assessment of Small and Medium Scale Industries Performance in Nigeria in Babcock Journal of Management and Social Sciences.1(2).

[7] Bititei, U.S., Suwignjo, P. \& Came, A.S. (2001). Strategy management through quantitative modeling of performance measurement systems. International Journal of production Economics 69, 15-22.

[8] Dawuda, A., \& Azeko, I. (2015). An Assessment of Financial Records Keeping Behaviour of Small Scale Businesses in Ghana: ACase Study of Bolgatanga Municipality. International Journal of Finance and Accounting, 4(3), 187-194. http://dx.doi.org.10.5923/j.ijfa.20150403.06.

[9] Emad, H. (2017). Accounting performance of SMEs and effect of accounting information system: a conceptual model. Global Journal of Management and Business Research: D Accounting and Auditing. 17(3). Online ISSN: 2249-4588 \& Print ISSN: 0975-5853.
[10] Ezejiofor, R. A, Ezenyirimba, E. \& Olise, C. M. (2014). The relevance of accounting records in small scale business: The Nigerian experience. International Journal of Academic Research in Business and Social Sciences. 4(12). ISSN: 2222-6990.

[11] Fitzgerald, L., Johnson, R., Brignall, S., Silverstro, R \& Voss, C. (2006). Performance measurement in service business. London (CIMA).

[12] Harash E., Alsaadi, J., \& Al-Timimi, S. (2014). Financial performance of SMEs - Evidence on the Influence of Environmental Uncertainty: A Conceptual Framework. Journal China-USA Business Review, 13, (8), 540-545.

[13] Ikechukwu C. (1993). Success Key Point Book Keeping and Accounts. Onitsha: Hybrid Publisher Limited.

[14] Ismail, N. A., \& King, M. (2007). Factors influencing the alignment of accounting information in small and medium sized Malaysian firms. Journal of Information System and Small Business, 1(1-2), 1-20.

[15] Keasy, K., \& Short, H. (1990). The accounting burdens facing small firms: An empirical research note. Journal of Accounting Business Research, 20(80), 307-313. http://dx.doi.org/10.1080/00014788.1990.9728889

[16] Lalin, H., \& Sabir, R. I. (2010). Research on Usage and Usefulness Perception of Financial Accounting Practices in Less Developing Countries: A case of Cambodia. Proceedings of the Proceedings of the 7th International Conference on Innovation \& Management, 1881-1885.

[17] Iopev, Luper and Kwanum, I.. M (2012) An Assessment of Risk Management of Small and Medium Scale Enterprises in Nigeria in Research Journal of Finance and Accounting 3(5) www.iiste.org

[18] Mensah, J. V., Tribe, M., \& Weiss, J. (2007). The smallscale manufacturing sector in Ghana: A source of dynamism or of subsistence income? Journal of International Development, 19(2), 253-273. http://dx.doi.org/10.1002/jid.1322

[19] Maseko, N.,\& Manyani,O.(2011). Accounting practices of SMEs in Zimbabwe: An investigative study of record keeping for performance measurement. A case study of Bindura. Journal of Accounting and Taxation 3(8), 158. http://dx.doi.org.10.5897JAT11.031.

[20] Mbroh, (2013) Accounting and Control Systems Practiced By Small and Micro Enterprise Owners within the Cape Coast Metropolitan Area of Ghana in Asian Journal of Business and Management SciencesVol. 1 No. 9 [28-47]

[21] Muchira, B. W. (2012). Record Keeping and Growth of Micro and Small Enterprises. A Case Study Municipally in Kenya. Masters of Business Administration (thesis) of Kenyatta University.

[22] Niswoger, C. R \& Philip E. Fess, (1969) Accounting Principles 10thEd. Cincinnati: South- Western Publishing Company. p1, 267

[23] Nwoye, M. I. (1991); Small business enterprises (How to start and succeed); Social Science Series Benin City Nigeria.

[24] Okoli, B. E. (2011). Evaluation of the accounting systems used by small scale enterprises in Nigeria: The Case of Enugu-South East Nigeria, Asian. Journal of Business Management, 3(4), 235-240. 
International Journal of Trend in Scientific Research and Development (IJTSRD) @ www.ijtsrd.com eISSN: 2456-6470

[25] Olatunji, T.E. (2013).The impact of accounting system on the performance of small and medium scale enterprises in Nigeria - A survey of SME's In Oyo StateNigeria. International Journal of Business and Management Invention ISSN (Online): 2319 - 8028, ISSN (Print): 2319 - 801X www.ijbmi.org 2(9).

[26] Onaolapo, A. A. \& Adegbite, T. A. (2014). The analysis of the impact of accounting records keeping on the performance of the small scale enterprises. International Journal of Academic Research in Business and Social Sciences. 4(1). ISSN: 2222-6990.

[27] Olaoye, C.O (2012) Fundamental of Financial Accounting 2 Ado-Ekiti: Jehovah-Jireh Publishers

[28] Ozatambgo, O.(2015). Financial Record Keeping In Religious Organizations: A Case Study of Catholic Church in Enugu Diocese.Understanding the context of electronic records management. Training in Electronic records management.

[29] Pickles, W. \& Lafferty, J. L. (1974) Accountancy London: ELBS and Pitman Publishing. p1101

[30] Ssekajugo, D., Tuyishime, E.,\& Kasenene, E. S. (2013). Performance of public institutions in Ngororero District, North Western Rwanda.

[31] Trivedi, S. M. (2010). An analysis of financial performance of state road Transport Corporation in Gujarat. Doctoral dissertation, Saurashtra University.

[32] Williams, J. R., Haka, S. F., Bettner, M. S., \& Carcello, J. V. (2008). Financial and Managerial Accounting. New York, NY: Mc Graw-Hill Irwin.

[33] Wood, F. (1979) Business Accounting 1 Third Ed. Essex: ELBS and Longman, p 251 